\title{
Panic buying pada pandemi COVID-19: Telaah literatur dari perspektif psikologi
}

\author{
Muhammad Abdan Shadiqi*, Rima Hariati, Khaerullah Fadhli Arasy Hasan, \\ Noor I'anah, \& Wita Al Istiqomah \\ Program Studi Psikologi, Fakultas Kedokteran, Universitas Lambung Mangkurat, Banjarbaru
}

\begin{abstract}
Abstrak
Pandemi COVID-19 memiliki berdampak pada kesehatan, sosial, ekonomi, hingga psikologis. Salah satu dampak dari COVID-19 adalah panic buying. Artikel ini ditujukan untuk mengulas panic buying melalui perspektif psikologi. Kami melakukan telaah literatur panic buying pada riset-riset terkini baik pada kasus pandemi COVID-19 hingga wabah penyakit serupa yang terjadi pada puluhan tahun silam. Pada bagian awal, artikel ini membandingkan definisi panic buying dengan istilah serupa, seperti buying frenzies, impulsive buying, dan compulsive buying. Kemudian, kami mengulas penjelasan psikologis di balik panic buying melalui perilaku konsumen, ketakutan dan kecemasan, stres, ketidakpastian, dan paparan media. Pada bagian terakhir, kami mengajukan beberapa solusi yang dapat dijadikan panduan kebijakan untuk mengatasi panic buying saat wabah pandemi terjadi.
\end{abstract}

Kata kunci: Panic buying, COVID-19, pandemi, psikologi

\begin{abstract}
COVID-19 pandemic has an impact on health, social, economic, and psychological. One of the effects of COVID-19 was panic buying. This article aims to review panic buying literature from a psychological perspective. We conducted study panic buying literature on the latest research references from the COVID-19 pandemic to the other disease outbreaks that occurred decades ago. In the first section, we compared the definition of panic buying with similar terms, such as buying frenzies, impulsive buying, and compulsive buying. Then, we expounded the psychological explanation behind panic buying through consumer behavior, fear and anxiety, stress, uncertainty, and media exposure. In the last section, we proposed several solutions that can be utilized as a policy guideline to control panic buying when a disease outbreak occurs.
\end{abstract}

Keywords: Panic buying, COVID-19, pandemic, psychology

\section{Pendahuluan}

Hingga 11 Mei 2020, WHO melaporkan sebanyak lebih 3,9 juta kasus corona virus disease 2019 atau COVID-19 terkonfirmasi di antara 215 negara (World Health Organization (WHO), 2020). Beberapa negara melaporkan terjadinya fenomena panic buying sebagai respon dari adanya pandemi ini. Dengan demikian, tidak hanya COVID-19, tetapi panic buying juga menyebar ke seluruh dunia. Mulai dari Singapura hingga Amerika Serikat melaporkan adanya antrian panjang di supermarket selama beberapa minggu akibat dari banyaknya konsumen yang ingin membeli barangbarang seperti beras, hand sanitizer hingga kertas toilet (Thukral, 2020). Indonesia sendiri, sesaat setelah pengumuman dua orang pertama yang positif terinfeksi COVID-19 pada 2 Maret 2020, beberapa stok barang seperti makanan pokok, hand sanitizer, hingga masker habis diserbu oleh masyarakat di Jakarta (Putra, 2020). Tidak hanya terjadi di Jakarta, fenomena ini juga terjadi di beberapa daerah lain, seperti Surabaya dan beberapa kota lainnya (Wahyudi, 2020).

Pada kajian psikologi, perilaku membeli masyarakat pada fenomena ini dikenal sebagai panic buying. Panic buying diartikan sebagai perilaku konsumen berupa pembelian produk dalam jumlah besar agar tidak mengalami kekurangan di masa depan (Shou, Xiong, \& Shen, 2011). Menurut sejarah, Honigsbaum (2013) melaporkan bahwa panic buying pertama kali muncul saat wabah flu Spanyol pada tahun 1918. Kemudian saat wabah Severe Acute Respiratory Syndrome (SARS) menyerang Hong Kong pada 2003, fenomena panic buying juga terjadi (Cheng, 2004; Fast, González, Wilson, \& Markuzon, 2015; Wai Man Fung \& Yuen Loke, 2010). Selain wabah, panic buying juga dapat terjadi saat muncul perkiraan bencana alam (Wai Man Fung \& Yuen Loke, 2010) hingga bencana non-alam seperti krisis akibat nuklir (Li, Wang, 
Gao, \& Shi, 2017; Zhao, Zhang, Tang, \& Kou, 2016). Pada pandemi COVID-19, Garfin, Silver, dan Holman (2020) berpendapat bahwa panic buying muncul sebagai respon stres. Kami menilai bahwa panic buying tidak sesederhana itu muncul karena adanya stres, tetapi ada penjelasan psikologi lain yang melandasinya.

Namun, hanya ada sedikit riset empiris yang mengupas tentang fenomena panic buying, kami menemukan setidaknya ada empat artikel yang menjelaskan panic buying pada pencarian referensi ilmiah di bidang psikologi. Pertama, artikel dari Garfin dkk. (2020) yang menjelaskan tentang stres sebagai pemicu panic buying. Kedua, artikel dari Wai Man Fung dan Yuen Loke (2010) yang meneliti tentang kesiapan keluarga saat menghadapi bencana, salah satu bagian temuannya menyinggung tentang panic buying. Ketiga, artikel Tsao, Raj, dan Yu (2019) membuat perhitungan model matematis penjualan barang saat situasi panic buying. Terakhir, artikel Bacon dan Corr (2020) yang menjelaskan bahwa panic buying terkait COVID-19 sebagai perilaku maladaptif karena adanya konflik psikologis dalam diri individu.

Selain jumlah artikel referensi ilmiah panic buying yang sedikit di bidang psikologi, kami berpendapat bahwa fenomena panic buying ini dapat terjadi kembali ketika suatu wilayah menunjukkan peningkatan angka kasus COVID-19 dan kondisi negatif psikologis di masyarakat. Untuk itu, kami berusaha menjelaskan fenomena panic buying melalui kajian ilmiah literatur lintas disiplin ilmu. Adapun dua hal yang menjadi fokus kajian kami adalah definisi panic buying dan perbandingan dengan konstruk psikologi lainnya serta faktor penyebab terjadinya panic buying. Secara khusus, kami menguraikan kedua tujuan tersebut melalui penjelasan dan temuan dari sumber referensi ilmiah. Kami berharap tulisan ini dapat menjadi dasar acuan pelaksanaan risetriset perilaku panic buying sekaligus menawarkan masukan-masukan untuk arah kebijakan dalam menghadapi dampak psikologis dan sosial dari pandemi COVID-19 ini.

\section{Metode Penelitian}

Artikel ini ditulis menggunakan pendekatan telaah literatur (literature review) yang terdiri dari bagian pendahuluan, metode penelitian, diskusi, dan kesimpulan (Kysh, 2013). Kysh (2013) dan American Psychological Association (2020) menerangkan bahwa telaah literatur bertujuan untuk membuat kesimpulan dan evaluasi pada suatu topik tertentu. Untuk menjelaskan fenomena panic buying, kami melakukan pencarian dengan menggunakan kata kunci "panic buying" dan "panic bought" di pangkalan data PsycArticles dan PsycINFO. Kami memulai pencarian artikel dari tahun 2003 hingga 2020, hal ini dikarenakan salah satu contoh wabah penyakit yang pernah menyerang beberapa negara, yaitu SARS terjadi pada tahun 2003. Kemudian, kami memperluas hasil pencarian yang ada, karena saat menggunakan pangkalan data pencarian khusus pada ilmu psikologi, kami hanya menemukan empat pencarian artikel (pangkalan data: PsycArticles dan PsycINFO). Kami menambahkan beberapa artikel yang ditelaah dari sejumlah 101 hasil pencarian di ScienceDirect. Di antara ratusan hasil pencarian tersebut terdiri dari 23 artikel dengan jenis: artikel telaah (review article), artikel penelitian (research article), surat atau korespondensi (correspondence), artikel diskusi, dan catatan editor. Alasan penggunaan keempat jenis artikel ini adalah karena minimnya riset-riset empiris yang mengkaji panic buying. Sementara pada pencarian artikel di pangkalan data Indonesia, yakni Gerba Rujukan Digital (Garuda), tidak ditemukan artikel yang berkaitan dengan panic buying.

Pada tujuan pertama, kami mengidentifikasi artikel-artikel yang relevan dengan tujuan pertama dari penulisan artikel ini, yaitu untuk menelaah definisi panic buying beserta perbandingannya dengan istilah lain yang serupa. Untuk membandingkan definisi konsep panic buying, kami menggunakan tambahan beberapa referensi yang relevan, yaitu konsep panik dan perilaku membeli, seperti "buying frenzies", "impulsive buying", dan "compulsive buying".

Pada tujuan kedua, kami berusaha menjelaskan faktor penyebab terjadinya panic buying pada peristiwa wabah penyakit. Tidak semua artikel yang kami telaah merupakan artikel studi empiris dari bidang psikologi, tetapi artikel yang kami pilih berkaitan dengan konsep perilaku, perasaan, dan pikiran terkait panic buying. Untuk menjawab tujuan kedua ini, kami meninjau artikel panic buying yang berkaitan dengan peristiwa wabah penyakit, seperti SARS, MERS, H1N1, dan COVID-19. Rincian daftar artikel ilmiah yang kami gunakan untuk menjelaskan faktor-faktor penyebab dapat dilihat pada tabel 1 di apendik.

\section{Temuan dan Diskusi}

\section{Definisi Panic buying}

Pada kajian sosiologi, panic atau panik populer merupakan bentuk perilaku kolektif (Oliver, 2013; Quarantelli, 2001; Shadiqi, in press). Istilah perilaku kolektif ini merujuk pada aksi yang muncul tiba-tiba, spontan, bukan aktivitas rutinitas, dan cenderung tidak sesuai norma (non-normatif) (Oliver, 2013). Zhao dkk. (2016) mengategorikan panic buying sebagai perilaku kolektif. Pada ilmu perilaku, khususnya 
psikiatri, panik erat dijelaskan sebagai gangguan panik atau serangan panik (Parks, 2013). Karakteristik panik pada perspektif gangguan kejiwaan ditandai dengan serangan panik secara berulangulang, tiba-tiba, dan tidak terduga (Parks, 2013). Secara khusus, Strahle dan Bonfield (1989) lebih cenderung mengaitkan kepanikan konsumen pada perilaku kolektif melalui kajian sosiologi. Namun, baik dari pandangan sosiologi maupun psikiatri, panik sama-sama ditandai dengan ciri perilaku yang muncul secara tiba-tiba. Jika dikaitkan lebih jauh dengan panic buying pada isu COVID-19, fenomena ini mempunyai benang merah yang sama, yaitu terjadi secara tiba-tiba dan tidak terkontrol.

Kepanikan berbelanja atau yang umumnya diistilahkan sebagai "panic buying" dapat dijelaskan sebagai perilaku konsumen berupa tindakan orang membeli produk dalam jumlah besar untuk menghindari kekurangan di masa depan (Shou dkk., 2011). Perilaku ini juga disebut sebagai perilaku penimbunan barang yang dilakukan oleh konsumen. Shou dkk. (2011) secara implisit merefleksikan panic buying dengan perbedaan antara jumlah pesanan dan permintaan yang mendasarinya, yang searah dengan antisipasi perubahan harga. Hal yang perlu digaris bawahi dalam definisi ini adalah konsumen membeli barang dalam jumlah banyak bukan bertujuan untuk mencari selisih harga yang akan timbul antara masa sekarang dan masa yang akan datang, tetapi bertujuan untuk menghindari kekurangan pasokan yang mungkin akan terjadi di masa depan.

Perbedaan panic buying dan buying frenzies. Pada bidang ekonomi, dikenal pula istilah buying frenzies. Meskipun kedua istilah ini merupakan perilaku pembelian barang dalam jumlah yang di luar batas kebutuhan normal, tetapi pertimbangan perilaku buying frenzies didasarkan pada diskriminasi harga antar waktu (Courty \& Nasiry, 2016). Pada perilaku panic buying lebih didasarkan pada kekhawatiran akan ketersediaan barang di masa depan (Shou dkk., 2011). Buying frenzies membuat orang berani membeli dengan harga yang lebih mahal karena ketidakjelasan penilaian suatu barang (Courty \& Nasiry, 2016; Kendall, 2018). Pembeda lainnya dapat dilihat pada contoh berikut: Pada fenomena wabah COVID-19, orang-orang membeli masker karena dilanda kekhawatiran akan habisnya stok masker, ini disebut dengan panic buying. Sedikit berkebalikan, buying frenzies terjadi karena orang khawatir akan harga masker yang semakin tidak masuk akal, sehingga membeli secara banyak dan berani membeli dengan harga berapapun di pasaran.
Perbedaan panic buying, impulsive buying, dan compulsive buying. Istilah lain yang mirip dengan panic buying juga dalam hal perilaku belanja adalah impulsive buying. Perilaku impulsive buying merupakan perilaku pembelian barang dengan sedikit atau tanpa pertimbangan setelah hasil dari dorongan mendadak dan kuat (Amos, Holmes, \& Keneson, 2013; Block \& Morwitz, 1999). Persamaan antara kedua perilaku ini terletak pada sedikitnya pertimbangan dan merupakan hasil dari dorongan yang mendadak dan kuat. Namun, perbedaannya adalah pada impulsive buying, sedikitnya pertimbangan dan dorongan yang mendadak didasari didorong oleh motif utilitarianistik (kegunaan barang) dan hedonik (bersenang-senang), kontrol diri yang rendah, dan mood positif (Iyer, Blut, Xiao, \& Grewal, 2019).

Istilah lain yang setara dengan impulsive buying adalah compulsive buying, keduanya samasama dikategorikan sebagai perilaku adiksi (Leite dan Silva, 2016). Lourenço Leite, Pereira, Nardi, dan Silva (2014) menjelaskan bahwa compulsive buying tidak masuk pada kriteria di Diagnostic and Statistical Manual of Mental Disorders ke-5 (DSM-V) dan umumnya dihubungkan dengan gangguan obsessive-compulsive. Beberapa diagnostik dari compulsive buying adalah perilaku konsumen yang maladaptif, berlebihan berbelanja, dan mengganggu fungsi kehidupan sosial pribadi (Faber, O'Guinn, \& Krych, 1987; Maraz, Griffiths, \& Demetrovics, 2016). Hartney (2020) menerangkan bahwa impulsive buying lebih cenderung tidak terencana, sedangkan compulsive buying lebih terencana. Dengan demikian, kami menilai compulsive buying lebih jauh berbeda pengertiannya dengan panic buying, karena perilaku adiktif ini bersifat terencana.

Berdasarkan uraian diatas, kami menyimpulkan bahwa panic buying merupakan perilaku belanja konsumen yang didorong oleh kekhawatiran dan ketakutan akan ketersediaan barang di masa depan dengan tetap mencari manfaat fungsional dari proses belanja namun dalam jumlah yang berlebihan atau di luar kebutuhan konsumen tersebut. Ciri-ciri perilaku ini ditandai dengan perilaku yang tiba-tiba, tidak terkontrol, dilakukan banyak orang, berlebihan, dan didasari oleh kekhawatiran.

\section{Penjelasan psikologis: Mengapa panic buying terjadi?}

Perilaku Konsumen. Dalam sebuah penelitian yang dilakukan András dan Tamás (2020) yang dilakukan di Hungaria mengenai panic buying yang terjadi akibat dari COVID-19 menjelaskan bahwa ancaman virus ini menyebabkan respon panik yang intensif terjadi pada Maret 2020. Mayoritas responden dalam penelitian ini 
melaporkan bahwa mereka mengalami peningkatan pengeluaran pada minggu pertama di tahap krisis ini. Selanjutnya, András dan Tamás menyatakan bahwa ancaman COVID-19 memiliki dampak besar pada seluruh sektor ritel di Hungaria akibat dari perubahan perilaku belanja pelanggan. Berdasarkan hasil survei dari penelitian tersebut, terjadi perubahan besar dalam frekuensi belanja, preferensi toko, pengeluaran, preferensi produk dan penolakan terhadap suatu barang. Ho, Chee, dan Ho (2020) menjelaskan permasalahan panic buying di Singapura yang terjadi setelah status tanggap bencana meningkat, orang-orang membeli barang demi menjaga persediaan makanan. András dan Tamás (2020) juga menemukan bahwa sebanyak $87 \%$ orang yang terlibat dalam survei melaporkan bahwa mereka melakukan pembelian ekstra untuk meningkatkan stok di rumah pada beberapa kelompok produk tertentu.

Istilah yang diajukan oleh Arafat dkk. (2020) untuk menjawab penyebab panic buying dari faktor perilaku konsumen, yaitu persepsi kelangkaan barang. Artinya, panic buying dapat terjadi karena banyak orang-orang menilai bahwa ada barang-barang tertentu yang akan langka saat terjadi wabah penyakit. Arafat dkk. (2020) menilai bahwa persepsi kelangkaan ini juga berkaitan dengan perasaan tidak aman (insecurity) dan ketidakstabilan suatu situasi. Kedua hal ini juga kami jelaskan lebih lanjut pada penjelasan faktor penyebab di bagian lain dari penjelasan psikologis ini.

Ketakutan dan kecemasan. Panic buying merupakan bentuk manifestasi dari kecemasan dan ketakutan individu akibat sebuah ancaman (Cheng, 2004). Lebih lanjut lagi, Cheng menjelaskan bahwa ketakutan atau kepanikan merupakan bentuk emosi dasar yang mengaktivasi respon 'fight-or-flight' yang memungkinkan individu merespon dengan cepat ketika menghadapi suatu bahaya. Berdasarkan studi Jinqiu (2003) serta Wilson V, Polyak, Blake, dan Collmann (2008) menerangkan bahwa panic buying dapat dipahami sebagai bentuk mekanisme bertahan hidup atau insting hidup yang membuat masyarakat takut mati, yang mana mereka melakukan hal tersebut sebagai usaha melindungi dan mempertahankan diri. Usaha pemenuhan kebutuhan fisiologis seringkali membuat orang berpikir dangkal yang menurut Jinqiu (2003) dapat menyebabkan kekurangan pasokan dan gangguan sosial. Penelitian Wilson V. dkk. (2008) memberikan penjelasan bahwa kecemasan yang tidak dapat dikendalikan akan melahirkan kepanikan. Kepanikan ini sendiri tidak akan terjadi jika masyarakat mampu mengutamakan pikiran rasionalnya. Sehingga perubahan perilaku dalam pembelian tidak akan terjadi.
Temuan Fast dkk. (2015) pada saat membandingkan kasus SARS pada 2003 dan kasus flu babi pada 2009 di Hong Kong dapat memperjelas peran kecemasan pada panic buying. Saat virus SARS menyerang Hong Kong pada 2003, muncul respon perilaku sosial seperti kecemasan tinggi (Leung, Lam, \& Cheng, 2020) dan panic buying (Cheng, 2004). Sebaliknya, ketika flu babi terjadi enam tahun kemudian 64\% penduduk Hong Kong melakukan aktivitas sehari-hari seperti biasa (Lau, Griffiths, Choi, \& Tsui, 2009), bahkan kecemasan mereka relatif rendah pada banyak penduduk (Cowling dkk., 2010). Menurut Fast dkk. (2015), hal ini dikarenakan oleh penduduk Hong Kong pada saat itu tidak terkejut akan kemunculan flu babi dan pemerintah cepat tanggap untuk menghadapi virus H1N1 berbulan-bulan sebelumnya. Hal ini menunjukkan bahwa pengalaman dan kesiapan menghadapi wabah juga memengaruhi respon panik masyarakat di sebuah wilayah. Namun, ketika wabah bersifat baru pada wilayah tertentu atau dianggap sebagai ancaman khusus, maka masyarakat cenderung lebih panik (Fast dkk., 2015). Kecemasan yang terjadi pada masyarakat luas dapat mengakibatkan terjadinya panic buying saat wabah COVID-19 (Roy dkk., 2020). Pada kasus COVID-19, perilaku panic buying terjadi karena orang-orang mengalami konflik psikologi, antara keinginan untuk tetap aman dengan keinginan untuk hidup secara normal dan menyenangkan (Bacon \& Corr, 2020). Perasaan tidak aman (insecurity) (Arafat dkk., 2020; Ippolito, Iozzo, Gregoretti, \& Cortegiani, 2020) menjadi terlihat sangat berkaitan dengan faktor ketakutan. Dengan demikian, dapat dipahami bahwa beberapa faktor penyebab yang memicu terjadinya panic buying adalah kondisi ketakutan, kecemasan, dan perasaan tidak aman.

Stres. Fast dkk. (2015) menuliskan dalam jurnalnya bahwa respon masyarakat terkait wabah biasanya tenang dan teratur, tetapi di beberapa kasus yang jarang terjadi penyebaran wabah penyakit juga bisa memicu gangguan sosial seperti kepanikan dan penimbunan alat medis. Respons sosial yang menunjukkan kecemasan yang parah termanifestasi menjadi perilaku yang mengkhawatirkan tentang suatu penyakit, seperti panic buying atau berpartisipasi dalam aksi protes (Fast dkk., 2015). Fenomena panic buying tampak menjadi sangat relevan jika dikaitkan dengan wabah COVID-19, karena orang cenderung menganggap sebuah ancaman virus baru memiliki risiko yang lebih tinggi dibandingkan dengan ancaman yang lebih umum seperti influenza (Hong \& Collins, 2006). Sebuah studi longitudinal menunjukkan bahwa respons stres meningkat saat ada kejadian yang mengancam dengan kesehatan fisik dan mental dari waktu ke waktu (Garfin 
dkk., 2020). Apalagi respon stres dapat meningkatkan suatu perilaku mencari bantuan yang tidak seimbang dan tidak tepat untuk dilakukan dalam menanggapi sebuah ancaman aktual (Garfin dkk., 2020). Sebagai contoh, panik dalam membeli barang tertentu yang dianggap penting seperti kertas toilet, kotak P3K, air kemasan botol dan hand sanitizer sebagai respon terhadap COVID-19. Padahal hal tersebut akan membawa dampak pada kekurangan stok barang dan melonjak-nya harga barang tersebut.

Ketidakpastian. Kurangnya informasi akibat tidak mengetahui maupun akibat kurangnya efektivitas komunikasi menyebabkan munculnya ambiguitas yang dapat menyebabkan penilaian terhadap suatu ancaman meningkat dan kepanikan muncul saat krisis kesehatan $(\mathrm{Wu}$, Huang, Zhang, He, \& Ming, 2020). Ini terjadi saat konteks krisis H1N1 atau flu babi di dunia, ketika meningkatnya ketidakpastian berbanding lurus dengan meningkatnya kontrol kecemasan (Taha, Matheson, \& Anisman, 2014). Pada kasus COVID19 , orang-orang dapat mengalami konflik psikologis, yakni antara usaha untuk mempertahankan rutinitas dengan menghadapi ketidakpastian berakhirnya pandemi ini (Sim, Chua, Vieta, \& Fernandez, 2020). Ketidakpastian juga berkaitan dengan konsumsi barang (Kalina \& Tilley, 2020), artinya berupa ketidakpastian ketersediaan barang. Di masa sekarang, ambiguitas yang terjadi dikombinasikan dengan sebuah ancaman yang tidak terlihat oleh panca indera seperti virus. Ketakutan dan kekhawatiran semakin memperburuk penyebaran informasi yang salah. Hal ini sesuai dengan apa yang ditulis Cheng (2004) dalam artikelnya bahwa panik muncul saat individu berpikir bahwa ada informasi yang disembunyikan atau hanya sebagian diungkapkan terkait wabah, karena ketakutan akan hal yang tidak diketahui sering memicu kecemasan dan reaksi panik. Ini menekankan pentingnya berita atau informasi yang jelas dan meyakinkan dari sumber yang terpercaya. Sebaliknya, Lunn dkk. (2020) menerangkan bahwa pemerintah seringkali melebih-lebihkan risiko kepanikan, sehingga memicu panic buying. Artinya, informasi harus disampaikan secara lengkap dan proporsional kepada masyarakat.

Peran paparan media. Masyarakat tidak akan panik jika mereka memiliki informasi yang tepat tentang peristiwa yang sedang terjadi. Namun karena masyarakat, dalam hal ini kami pahami, masih kurang sosialisasi yang komprehensif sehingga seperti yang dikatakan Jinqiu (2003), kekurangan informasi dan tambahan desas-desus mengakibatkan masyarakat menjadi panik. Peristiwa seperti ini terjadi saat virus SARS menyerang Tiongkok, beberapa hal yang memicu kepanikan sosial hingga orang-orang panic buying membeli obat-obatan adalah kurangnya informasi resmi, cerita dari mulut ke mulut melalui pesan singkat dan media sosial (Qiu, Chu, Mao, \& Wu, 2018). Kurangnya informasi yang dibutuhkan masyarakat dari pihak berwajib serta maraknya berita palsu juga kami yakini berpengaruh pada terjadinya panic buying. Menurut Cheng (2004) menonton berita dan ketidakjelasan informasi memengaruhi kepanikan pada diri individu. Hal ini juga didukung oleh penelitian yang dilakukan oleh Garfin dkk. (2020) tentang pengaruh paparan media terhadap kecemasan dan stres masyarakat terkait krisis COVID-19. Paparan media ini dapat berkaitan dengan informasi adanya kelangkaan sumber daya dan kebutuhan sehari-hari (Roy dkk., 2020). Peran paparan media seperti ini juga terjadi pada saat virus Ebola terjadi di Amerika Serikat tahun 2014 (Thompson, Garfin, Holman, \& Silver, 2017). Semakin individu menonton atau mengikuti berita terkait wabah maka hal tersebut akan memicu respon panik pada individu. Menonton banyak berita akan membuat seseorang semakin banyak berpikir tentang wabah dan menyebabkan kepanikan (Cheng, 2004). Banjir informasi yang kontradiktif juga dapat menyebabkan panic buying saat wabah COVID-19 (Mesa Vieira, Franco, Gómez Restrepo, \& Abel, 2020).

Fast dkk. (2015) juga menjelaskan bahwa kepanikan individu terkait wabah juga dipicu oleh rangsangan dari media massa dan komunikasi antar-tetangga di sebuah jejaring sosial. Berdasarkan perspektif psiko-sosiologis, kepanikan dipandang sebagai sifat bawaan dari kecemasan pribadi, yaitu ketika orang merasa tegang terkait kehidupan mereka, maka individu tersebut cenderung sangat sensitif untuk menyumbangkan kekhawatiran dalam pola sosial yang lebih luas (Cheng, 2004). Perilaku semacam ini khasnya adalah apa yang disebut dengan "following the crowd" atau "going with the flow" (Cheng, 2004). Masyarakat saling berkomunikasi dengan tetangganya dan akan condong mengadopsi pendapat yang mengkhawatirkan daripada pendapat yang menenangkan.

\section{Dinamika Psikologi Sosial dari Perilaku Panic Buying}

Kami mengajukan argumentasi bahwa teori yang dapat menjelaskan dinamika psikologi sosial dari perilaku panic buying adalah teori kognitif sosial (cognitive social theory) dari Albert Bandura. Bandura (2012) menerangkan bahwa teori ini secara orisinal awalnya disebut sebagai teori belajar sosial (social learning theory). Argumentasi kami setidaknya didukung oleh argumentasi Arafat dkk. (2020) dan Zheng dkk. 
(2020). Ketepatan penggunaan teori kognitif sosial juga didasarkan pada pertimbangan peran dari beberapa faktor penyebab yang telah kami identifikasi pada bagian sebelumnya.

Bandura (2012) menilai bahwa penggunaan istilah teori kognitif sosial muncul karena pikiran, motivasi, dan tindakan manusia ditentukan oleh faktor 'sosial' dan proses 'kognitif'. Bandura (2012) mengajukan "triadic reciprocal causation" untuk menjelaskan teori kognitif sosial, yaitu fungsi psikologis manusia berasal dari interaksi kausalitas dari dimensi interpersonal (personal=P), perilaku (behavioral=B), dan lingkungan (environmental= E).

Pada dimensi interpersonal, orang-orang yang melakukan panic buying mengalami kondisi psikologi internal yang khas. Sebagian orang mengalami beberapa kondisi berikut: Konflik psikologis, stres, ketakutan, kecemasan, perasaan tidak aman, dan/atau persepsi ketidakpastian. Pada dimensi lingkungan, ketersediaan barang, informasi yang bersumber dari media massa dan jejaring sosial tersebar melalui lingkungan sosial mereka, seperti antar-tetangga, menjadi salah satu penyebab terjadinya perilaku. Selain itu, penting untuk digaris bawahi adalah kondisi pandemi juga menjadi faktor lingkungan yang memainkan peran begitu besar pada panic buying. Pada dimensi ketiga, perilaku itu sendiri yaitu munculnya perilaku panic buying. Tiga dimensi ini saling berperan dan memengaruhi satu sama lain, ketiadaan salah satu dimensi dapat menurunkan level perilaku panic buying. Selanjutnya, proses yang menjembatani ketiga dimensi ini adalah proses kognitif, yakni individu menggunakan pikiran mereka untuk mengolah dan mengevaluasi informasi. Sementara, proses sosial bekerja saat individu membuat pertimbangan perilaku berdasarkan pengaruh sosial yang terjadi saat masa pandemi. Dinamika ketiga dimensi ini dapat dilihat pada gambar 1 .

\section{Gambar 1.}

Dinamika teori kognitif sosial pada panic buying
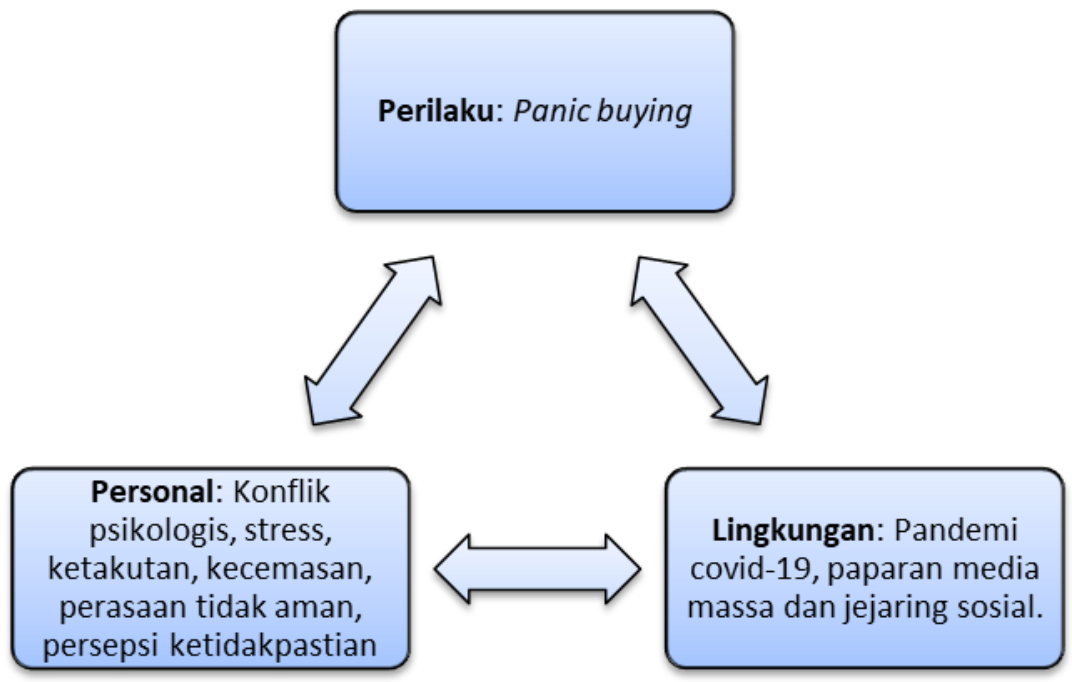

\section{Kesimpulan}

Panic buying terjadi pada peristiwa wabah penyakit hingga bencana alam dan non-alam lainnya, begitu halnya pada wabah COVID-19 ini. Panic buying yang dilakukan oleh konsumen seringkali mengarah kepada hal-hal negatif seperti antrian panjang, kehabisan stok dalam jumlah besar, kecemasan yang luar biasa, hingga akhirnya secara signifikan ber-dampak negatif pada pasar (Shou dkk., 2011). Sehingga, panic buying menjadi suatu hal yang perlu diatasi saat menghadapi keadaan maupun krisis apapun. Melalui artikel ini, kami dapat menjelaskan lebih dalam perbedaan antara panic buying dengan buying frenzies, compulsive buying, dan impulsive buying. Ciri-ciri khas dari panic buying adalah perilaku yang tiba-tiba, tidak terkontrol, terjadi pada banyak orang, terlihat berlebihan, dan disebabkan oleh kekhawatiran. Artikel ini juga memaparkan faktor penyebab perilaku panic buying, yaitu faktor dari perilaku konsumen (munculnya persepsi kelangkaan barang), adanya ketakutan, kecemasan, perasaan tidak aman, konflik psikologis, stres, persepsi ketidakpastian, dan paparan media. Kami juga mengajukan model dinamika psikologi sosial yang dapat memicu munculnya panic buying menggunakan teori kognitif sosial.

Tulisan ini tentu masih terdapat kekurangan, karena keterbatasan hasil-hasil riset yang dikutip dari bidang psikologi. Kami juga menemu- 
kan hanya sedikit artikel ilmiah yang mengajukan saran kebijakan terkait panic buying, bahkan kami belum menemukan riset-riset panic buying yang menjelaskan efektivitas kebijakan-kebijakan dilaksanakan untuk menghadapi wabah pandemi seperti ini. Padahal wabah seperti ini telah terjadi berkali-kali sejak puluhan hingga ratusan tahun yang lalu.

Untuk itu, pada bagian kesimpulan ini, kami memberikan beberapa saran implikasi praktis menghadapi panic buying, yaitu (1) membatasi penjualan barang, misal setiap orang boleh membeli dengan jumlah tertentu setiap waktu tertentu (per minggu) dan penerapan besaran harga berkali-kali lipat jika konsumen membeli lebih dari jumlah yang ditentukan; (2) membuat aturan prioritas bagi orang lanjut usia dan anakanak; (3) menguatkan peran otoritas dalam mengontrol harga, mengatur penyaluran barang, dan menindak oknum yang merugikan konsumen; (4) menyediakan pembelian barang secara daring dengan tetap menerapkan aturan jumlah barang dan prioritas pembeli; (5) menyebarkan informasi positif, jelas, terbuka, dan proporsional mengenai ketersediaan barang; (6) menekan penyebaran informasi yang menyesatkan dan palsu (hoaks).

\section{Daftar Pustaka}

American Psychological Association. (2020). Publication manual of the American Psychological Association (7th ed.). American Psychological Association.

Amos, C., Holmes, G. R., \& Keneson, W. C. (2013). A meta-analysis of consumer impulse buying. Journal of Retailing and Consumer Services, 1-12.

https://doi.org/10.1016/j.jretconser.2013 .11 .004

András, K., \& Tamás, S. T. (2020). Panic buying in Hungary during COVID-19 disease. https://doi.org/10.13140/RG.2.2.21264.7 6800

Arafat, S. M. Y., Kar, S. K., Marthoenis, M., Sharma, P., Apu, E. H., Kabir, R., ... Kabir, R. (2020). Psychological underpinning of panic buying during pandemic (COVID-19). Psychiatry Research Received. https://doi.org/10.1016/j.psychres.2020. 113061

Bacon, A. M., \& Corr, P. J. (2020). Coronavirus (COVID-19) in the United Kingdom: A personality-based perspective on concerns and intention to self-isolate. British Journal of Health Psychology, 1-10. https://doi.org/10.1111/bjhp.12423

Bandura, A. (2012). Social cognitive theory. In P. van Lange, A. W. Kruglanski, \& E. T. Higgins
(Eds.), Handbook of Theories of Social Psychology, Volume 1 (pp. 349-373). Sage.

Block, L. G., \& Morwitz, V. G. (1999). Shopping lists as an external memory aid for grocery shopping: Influences on list writing and list fulfillment. Journal of Consumer Psychology, 8(4), 343-375. https://doi.org/10.1207/s15327663jcp08 04_01

Cheng, C. (2004). To be paranoid is the standard? Panic responses to SARS outbreak in the Hong Kong special administrative region a global disease : Brief Epidemiology. Asian Perspective, 28(1), 67-98. Retrieved from https://www.jstor.org/stable/42704444

Courty, P., \& Nasiry, J. (2016). Product Launches and Buying Frenzies: A Dynamic Perspective. Production and Operations Management, 25(1), 143-152. https://doi.org/10.1111/poms.12394

Cowling, B. J., Ng, D. M. W., Ip, D. K. M., Liao, Q., Lam, W. W. T., Wu, J. T., ... Fielding, R. (2010). Community Psychological and Behavioral Responses through the First Wave of the 2009 Influenza A(H1N1) Pandemic in Hong Kong. The Journal of Infectious Diseases, 202(6), 867-876. https://doi.org/10.1086/655811

Faber, R. J., O'Guinn, T. C., \& Krych, R. (1987). Compulsive Consumption. Advances in Consumer Research, 14, 132-135. Retrieved from https://www.acrwebsite.org/volumes/66 70/volumes/v14/NA-14

Fast, S. M., González, M. C., Wilson, J. M., \& Markuzon, N. (2015). Modelling the propagation of social response during a disease outbreak. Journal of the Royal Society Interface, 12(104). https://doi.org/10.1098/rsif.2014.1105

Garfin, D. R., Silver, R. C., \& Holman, E. A. (2020). The novel coronavirus (COVID-2019) outbreak: Amplification of public health consequences by media exposure. Health Psychology : Official Journal of the Division of Health Psychology, American Psychological Association. https://doi.org/10.1037/hea0000875

Hartney, E. (2020). The difference between compulsive and impulsive shopping. Retrieved April 12, 2020, from Verywellmind.com website: https://www.verywellmind.com/differenc e-between-compulsive-and-impulsiveshopping-22336\%0A

Ho, C. S., Chee, C. Y., \& Ho, R. C. (2020). Mental Health Strategies to Combat the Psychological Impact of COVID-19 Beyond Paranoia and Panic. Annals of the Academy 
of Medicine, Singapore, 49(1), 1-3. Retrieved from https://www.ncbi.nlm.nih.gov/pubmed/3 2200399

Hong, S., \& Collins, A. (2006). Societal responses to familiar versus unfamiliar risk: Comparisons of influenza and SARS in Korea. Risk Analysis, 26(5), 1247-1257. https://doi.org/10.1111/j.15396924.2006.00812.x

Honigsbaum, M. (2013). Regulating the 1918-19 pandemic: Flu, stoicism and the northcliffe press. Medical History, 57(2), 165-185. https://doi.org/10.1017/mdh.2012.101

Ippolito, M., Iozzo, P., Gregoretti, C., \& Cortegiani, A. (2020). Counterfeit filtering facepiece respirators are posing an additional risk to healthcare workers during COVID-19 Pandemic. American Journal of Infection Control. https://doi.org/10.1016/j.ajic.2020.04.02 0

Iyer, G. R., Blut, M., Xiao, S. H., \& Grewal, D. (2019). Impulse buying: A meta-analytic review. Journal of the Academy of Marketing Science. https://doi.org/10.1007/s11747019-00670-w

Jinqiu, Z. (2003). The SARS Epidemic Under China's Media Policy. Media Asia, 30(4), 191-196.

https://doi.org/10.1080/01296612.2003. 11726722

Kalina, M., \& Tilley, E. (2020). "This is our next problem": Cleaning up from the COVID-19 response. Waste Management. https://doi.org/10.1016/j.wasman.2020.0 5.006

Kendall, C. (2018). Market panics, frenzies, and informational efficiency: Theory and experiment. American Economic Journal: Microeconomics., 1422(2012). Retrieved from

https://www.marshall.usc.edu/sites/defa ult/files/chadkend/intellcont/kendallpanicsexp-6.pdf

Kysh, L. (2013). What's in a name?: The difference between a systematic review and a literature review and why it matters. Medical Library Group of Southern California \& Arizona (MLGSCA) and the Northern California and Nevada Medical Library Group (NCNMLG) Joint Meeting. https://doi.org/10.6084/m9.figshare.766 364

Lau, J. T. F., Griffiths, S., Choi, K. C., \& Tsui, H. Y. (2009). Widespread public misconception in the early phase of the H1N1 influenza epidemic. Journal of Infection, 59(2), 122127. https://doi.org/10.1016/j.jinf.2009.06.00 4

Leite, P. L., \& Silva, A. C. (2016). Psychiatric and socioeconomic aspects as possible predictors of compulsive buying behavior. Trends in Psychiatry and Psychotherapy, 38(3), 141-146. https://doi.org/10.1590/2237-60892015-0057

Leung, C. C., Lam, T. H., \& Cheng, K. K. (2020). Mass masking in the COVID-19 epidemic: people need guidance. The Lancet, 395(10228), 945. https://doi.org/10.1016/S01406736(20)30520-1

Li, X., Wang, Z., Gao, C., \& Shi, L. (2017). Reasoning human emotional responses from largescale social and public media. Applied Mathematics and Computation, 310, 182193.

https://doi.org/10.1016/j.amc.2017.03.03 1

Lourenço Leite, P., Pereira, V. M., Nardi, A. Ô. E., \& Silva, A. C. (2014). Psychotherapy for compulsive buying disorder: A systematic review. Psychiatry Research, 219(3), 411419.

https://doi.org/10.1016/j.psychres.2014. 05.037

Lunn, P., Belton, C., Lavin, C., Mcgowan, F., Timmons, S., \& Robertson, D. (2020). Using behavioural science to help fight the coronavirus. Behavioural Research Unit, (656), 1-24. Retrieved from https://www.esri.ie/publications/usingbehavioural-science-to-help-fight-thecoronavirus

Maraz, A., Griffiths, M. D., \& Demetrovics, Z. (2016). The prevalence of compulsive buying: A meta-analysis. Addiction, 111(3), 408-419.

https://doi.org/10.1111/add.13223

Mesa Vieira, C., Franco, O. H., Gómez Restrepo, C., \& Abel, T. (2020). COVID-19: The forgotten priorities of the pandemic. Maturitas, 136(April), 38-41. https://doi.org/10.1016/j.maturitas.2020. 04.004

Oliver, P. (2013). Collective action (collective behavior). In D. A. Snow, D. della Porta, B. Klandermans, \& D. McAdam (Eds.), The Wiley-Blackwell encyclopedia of social and political movements (pp. 1-5). https://doi.org/10.1002/9780470674871 .wbespm032

Parks, P. J. (2013). Panic Disorder. San Diego, CA: Reference Point Press.

Putra, N. P. (2020). Headline: Virus Corona picu panic buying makanan, masker, hand sanitizer, bagaimana meredamnya? 
Liputan6.

Retrieved from https://www.liputan6.com/news/read/4 193886/headline-virus-corona-picupanic-buying-makanan-masker-handsanitizer-bagaimana-meredamnya

Qiu, W., Chu, C., Mao, A., \& Wu, J. (2018). The impacts on health, society, and economy of SARS and H7N9 Outbreaks in China: A Case Comparison Study. Journal of Environmental and Public Health, 2018. https://doi.org/10.1155/2018/2710185

Quarantelli, E. L. (2001). The sociology of panic. In Working paper. USA.

Roy, D., Tripathy, S., Kar, S. K., Sharma, N., Verma, S. K., \& Kaushal, V. (2020). Study of knowledge, attitude, anxiety \& perceived mental healthcare need in Indian population during COVID-19 pandemic. Asian Journal of Psychiatry, 51(April). https://doi.org/10.1016/j.ajp.2020.10208 3

Shadiqi, M. A. (in press). Aksi kolektif: Jenis, penyebab, dan konsekuensi dari sudut pandang psikologi. Dalam W. Yustisia, M. A. Hakim, \& R. Ardi, Psikologi Politik.

Shou, B., Xiong, H., \& Shen, Z. M. (2011). Consumer Panic buying and Quota Policy under Supply Disruptions. In Working paper. Hong Kong.

Sim, K., Chua, H. C., Vieta, E., \& Fernandez, G. (2020). The anatomy of panic buying related to the current COVID-19 pandemic. Psychiatry Research, 288, 113015. https://doi.org/10.1016/j.psychres.2020. 113015

Strahle, W. M., \& Bonfield, E. H. (1989). Understanding Consumer Panic: a Sociological Perspective. In NA (Ed.), Advances in Consumer Research (pp. 567573). Retrieved from https://www.acrwebsite.org/volumes/69 64/volumes/v16/NA-16

Taha, S. A., Matheson, K., \& Anisman, H. (2014). H1N1 Was Not All That Scary: Uncertainty and stressor appraisals predict anxiety related to a coming viral threat. Stress and Health, 30(2), 149-157. https://doi.org/10.1002/smi.2505

Thompson, R. R., Garfin, D. R., Holman, E. A., \& Silver, R. C. (2017). Distress, Worry, and Functioning Following a Global Health Crisis: A National Study of Americans' Responses to Ebola. Clinical Psychological Science, 5(3), 513-521. https://doi.org/10.1177/2167702617692 030
Thukral, N. (2020, March 21). Panic buying, lockdowns may drive world food inflation FA0, analysts. The Guardian. Retrieved from https://www.theguardian.pe.ca/news/wo rld/panic-buying-lockdowns-may-driveworld-food-inflation-fao-analysts427669/

Tsao, Y. C., Raj, P. V. R. P., \& Yu, V. (2019). Product substitution in different weights and brands considering customer segmentation and panic buying behavior. Industrial Marketing Management, 77(September 2017), 209-220. https://doi.org/10.1016/j.indmarman.20 18.09.004

Wahyudi, E. (2020). Aprindo sebut panic buying di 6 kota pasca pengumuman corona. Tempo.Co. Retrieved from https://bisnis.tempo.co/read/1315098/a prindo-sebut-panic-buying-di-6-kotapasca-pengumuman-corona/full\&view $=\mathrm{ok}$

Wai Man Fung, O., \& Yuen Loke, A. (2010). Disaster preparedness of families with young children in Hong Kong. Scandinavian Journal of Public Health, 38(8), 880-888. https://doi.org/10.1177/1403494810382 477

Wilson V, J. M., Polyak, M. G., Blake, J. W., \& Collmann, J. (2008). A heuristic indication and warning staging model for detection and assessment of biological events. Journal of the American Medical Informatics Association, 15(2), 158-171. https://doi.org/10.1197/jamia.M2558

World Health Organization (WHO). (2020). Novel Coronavirus 2020. Retrieved April 12, 2020, from World Health Organization website:

https://www.who.int/emergencies/diseas es/novel-coronavirus-2019

Wu, H., Huang, J., Zhang, C. J., He, Z., \& Ming, W. (2020). Facemask shortage and the coronavirus disease (COVID-19) outbreak: Reflection on public health measures. MedRxiv, 000, 2020.02.11.20020735. https://doi.org/10.1101/2020.02.11.2002 0735

Zhao, Y., Zhang, L., Tang, M., \& Kou, G. (2016). Bounded confidence opinion dynamics with opinion leaders and environmental noises. Computers and Operations Research, 74, 205-213. https://doi.org/10.1016/j.cor.2015.07.02 2 


\section{Apendik.}

Tabel 1.

Ringkasan artikel yang masuk dalam proses peninjauan

\begin{tabular}{|c|c|c|c|c|c|}
\hline No & Penulis & Tahun & $\begin{array}{l}\text { Jenis } \\
\text { artikel }\end{array}$ & Bencana & $\begin{array}{c}\text { Penjelasan Utama yang } \\
\text { diulas }\end{array}$ \\
\hline 1 & $\begin{array}{l}\text { András dan } \\
\text { Tamás }\end{array}$ & $(2020)$ & $\begin{array}{l}\text { Working } \\
\text { paper }\end{array}$ & Wabah COVID-19 & $\begin{array}{l}\text { Faktor penyebab: ditinjau } \\
\text { dari perilaku konsumen di } \\
\text { Hungaria. }\end{array}$ \\
\hline 2 & Arafat dkk. & $(2020)$ & $\begin{array}{l}\text { Surat } \\
\text { Korespon } \\
\text { densi }\end{array}$ & Wabah COVID-19 & $\begin{array}{l}\text { Faktor penyebab: persepsi } \\
\text { kelangkaan barang dan } \\
\text { perasaan tidak aman }\end{array}$ \\
\hline 3 & Bacon dan Corr & $(2020)$ & $\begin{array}{l}\text { Artikel } \\
\text { Penelitian }\end{array}$ & Wabah COVID-19 & $\begin{array}{l}\text { Faktor penyebab: konflik } \\
\text { psikologis }\end{array}$ \\
\hline 4 & Cheng & $(2004)$ & $\begin{array}{l}\text { Artikel } \\
\text { Penelitian }\end{array}$ & Wabah SARS & $\begin{array}{l}\text { Faktor penyebab: } \\
\text { ketakutan. }\end{array}$ \\
\hline 5 & Cowling dkk. & $(2010)$ & $\begin{array}{l}\text { Artikel } \\
\text { Penelitian }\end{array}$ & Wabah Flu Babi & $\begin{array}{l}\text { Faktor penyebab: } \\
\text { kecemasan }\end{array}$ \\
\hline 6 & Fast dkk. & (2015) & $\begin{array}{l}\text { Artikel } \\
\text { Penelitian }\end{array}$ & $\begin{array}{l}\text { Wabah SARS dan } \\
\text { Flu Babi (H1N1) }\end{array}$ & $\begin{array}{l}\text { Faktor penyebab: } \\
\text { kecemasan dan stres }\end{array}$ \\
\hline 7 & Garfin dkk. & $(2020)$ & $\begin{array}{l}\text { Artikel } \\
\text { Komentar }\end{array}$ & Wabah COVID-19 & Faktor penyebab: stres \\
\hline 8 & Ho dkk. & $(2020)$ & $\begin{array}{l}\text { Artikel } \\
\text { Komentar }\end{array}$ & Wabah COVID-19 & $\begin{array}{l}\text { Faktor penyebab: ditinjau } \\
\text { dari keinginan memenuhi } \\
\text { persediaan di Singapura. }\end{array}$ \\
\hline 9 & $\begin{array}{l}\text { Hong dan } \\
\text { Collins }\end{array}$ & $(2006)$ & $\begin{array}{l}\text { Artikel } \\
\text { Penelitian }\end{array}$ & Wabah SARS & $\begin{array}{l}\text { Faktor penyebab: ancaman } \\
\text { risiko dari wabah }\end{array}$ \\
\hline 10 & Ippolito dkk. & $(2020)$ & $\begin{array}{l}\text { Artikel } \\
\text { Penelitian }\end{array}$ & Wabah COVID-19 & $\begin{array}{l}\text { Faktor penyebab: perasaan } \\
\text { tidak aman }\end{array}$ \\
\hline 11 & Jinqiu & $(2003)$ & $\begin{array}{l}\text { Artikel } \\
\text { Penelitian }\end{array}$ & Wabah SARS & $\begin{array}{l}\text { Faktor penyebab: } \\
\text { ketakutan dan insting } \\
\text { pertahanan diri }\end{array}$ \\
\hline 12 & $\begin{array}{l}\text { Karlina dan } \\
\text { Tilley }\end{array}$ & $(2020)$ & $\begin{array}{l}\text { Artikel } \\
\text { Diskusi }\end{array}$ & Wabah COVID-19 & $\begin{array}{l}\text { Faktor penyebab: persepsi } \\
\text { ketidakpastian }\end{array}$ \\
\hline 13 & Lau dkk. & (2009) & $\begin{array}{l}\text { Artikel } \\
\text { Penelitian }\end{array}$ & Wabah Flu Babi & $\begin{array}{l}\text { Faktor penyebab: } \\
\text { kecemasan }\end{array}$ \\
\hline 14 & Leung dkk. & $(2020)$ & $\begin{array}{l}\text { Surat } \\
\text { Korespon } \\
\text { densi }\end{array}$ & Wabah COVID-19 & $\begin{array}{l}\text { Faktor penyebab: } \\
\text { kecemasan }\end{array}$ \\
\hline 15 & Lun dkk. & $(2020)$ & $\begin{array}{l}\text { Working } \\
\text { paper }\end{array}$ & Wabah COVID-19 & $\begin{array}{l}\text { Faktor penyebab: } \\
\text { informasi dari otoritas }\end{array}$ \\
\hline
\end{tabular}




\begin{tabular}{|c|c|c|c|c|c|}
\hline 16 & $\begin{array}{l}\text { Mesa Vieira } \\
\text { dkk. }\end{array}$ & $(2020)$ & $\begin{array}{l}\text { Artikel } \\
\text { Penelitian }\end{array}$ & Wabah COVID-19 & $\begin{array}{l}\text { Faktor penyebab: } \\
\text { informasi kontradiktif }\end{array}$ \\
\hline 17 & Qiu dkk. & (2018) & $\begin{array}{l}\text { Artikel } \\
\text { Penelitian }\end{array}$ & $\begin{array}{l}\text { Wabah SARS dan } \\
\text { H7N9 }\end{array}$ & $\begin{array}{l}\text { Faktor penyebab: sumber } \\
\text { informasi }\end{array}$ \\
\hline 18 & Roy dkk. & (2020) & $\begin{array}{l}\text { Artikel } \\
\text { Penelitian }\end{array}$ & Wabah COVID-19 & $\begin{array}{l}\text { Faktor penyebab: } \\
\text { kecemasan dan informasi }\end{array}$ \\
\hline 19 & Sim dkk. & (2020) & $\begin{array}{l}\text { Surat } \\
\text { Korespon } \\
\text { densi }\end{array}$ & Wabah COVID-19 & $\begin{array}{l}\text { Faktor penyebab: konflik } \\
\text { psikologis }\end{array}$ \\
\hline 20 & Taha dkk. & (2020) & $\begin{array}{l}\text { Artikel } \\
\text { Penelitian }\end{array}$ & Wabah Flu Babi & $\begin{array}{l}\text { Faktor penyebab: persepsi } \\
\text { ketidakpastian }\end{array}$ \\
\hline 21 & Thompson dkk. & (2017) & $\begin{array}{l}\text { Artikel } \\
\text { Penelitian }\end{array}$ & Wabah Ebola & $\begin{array}{l}\text { Faktor penyebab: paparan } \\
\text { media }\end{array}$ \\
\hline 22 & Wilson dkk. & (2008) & $\begin{array}{l}\text { Artikel } \\
\text { Penelitian }\end{array}$ & $\begin{array}{l}\text { Wabah SARS, Rift } \\
\text { Valley fever } \\
\text { (RVF), } \\
\text { Venezuelan } \\
\text { equine } \\
\text { encephalitis } \\
\text { (VEE) }\end{array}$ & $\begin{array}{l}\text { Faktor penyebab: } \\
\text { ketakutan, insting } \\
\text { pertahanan diri, dan } \\
\text { kecemasan }\end{array}$ \\
\hline 23 & Wu dkk. & $(2020)$ & $\begin{array}{l}\text { Artikel } \\
\text { Penelitian }\end{array}$ & Wabah COVID-19 & $\begin{array}{l}\text { Faktor penyebab: } \\
\text { ambiguitas informasi }\end{array}$ \\
\hline
\end{tabular}

